Mamba'ul 'Ulum, Vol. 15, No. 2, Oktober 2019: 217-224

\title{
DAKWAH DALAM KONTEKS PENDIDIKAN
}

\author{
Mukhlis Fathurrohman
}

Institut Islam Mamba'ul 'Ulum Surakarta

e-mail: $\underline{\text { mukhlis@gmail.com }}$

\begin{abstract}
Abstrak: Di masa modern sekarang, banyak berdiri sekolah-sekolah, bahkan tumbuh subur berbagai kampus-kampus baru di daerah. Sekarang sekolah ke-Islaman sudah menjadi trend, banyak orang tua berlomba-lomba memasukan anaknya ke sekolah ke-Islaman. Minimnya pengetahuan agama dimasa sekarang, menjadikan generasi muda kurang terkendali. Kegiatan yang dilakukan banyak yang kurang bermanfaat. Beberapa remaja lebih memilih nongkrong di kafe daripada menghadiri masjid. Bahkan bermain game online lebih menyenangkan dibandingkan membaca Al-Quran. Melalui pendidikan disekolah maupun pendidikan non formal, tiap orang bisa berdakwah sesuai dengan apa yang dipahami. Dimulai dari keluarga, kerabat, tetangga, komunitas sampai di lingkup yang lebih luas. Mengingatkan dan menyampaikan ilmu yang dimiliki adalah sebuah keharusan.Mengingatkan akan menjaga kelangsungan umat Islam sendiri untuk menghadapi modernisasi. Tidak hanyut dengan berbagai kemajuan yang terjadi. Sedangkan ilmu yang disampaikan akan membuat terus berkembang, menjadi beberapa cabang ilmu dan tentu untuk manfaat yang lebih besar. Dakwah dan pendidikan yang diberikan berdasar kepada orisinilitas dan kekinian. Orisinilitas berpegang terhadap nilai-nilai Islam dan berdasarkan penemuan-penemuan terbaru dimasa sekarang. Penyesuaian dengan kondisi sekarang sangat penting guna menghadapi segala permasalahan yang nyata.
\end{abstract}

Kata kunci: dakwah, pendidikan

\section{PENDAHULUAN}

Menurut Yulvanic A. Nurohman Secara umum dakwah memiliki pengertian menerangkan dan menyampaikan dalam kaitannya terhadap orang- orang yang menolak dan menentang Islam, serta membentuk dalam kaitannya orang yang telah menerima Islam. Dakwah dilakukan Nabi Muhammad Saw pada masa beliau setelah diangkat menjadi rasul menyeru kepada penduduk Mekkah untuk menyembah Allah Swt, menghilangkan pemujaan kepada berhala setelah masuk Islam. Dakwah yang dilakukan pada masa Rasulullah tidaklah mudah, banyak penolakan dari penduduk Mekkah, bahkan beberapa keluarga pun ikut menolak. Firman Allah Swt: "Kewajiban Rasul tidak lain hanyalah menyampaikan" (QS. Al-Maidah: 99). Berbeda dengan zaman dakwah Rasulullah Saw, pada masa tersebut belum banyak orang yang memeluk agama Islam, perlu penyadaran dari awal agar mau mengikuti ajakan yang diserukan. Namun, pada masa sekarang, banyak orang mengaku beragama Islam, akan tetapi tidak menjalankan sesuai ajaran yang telah ditetapkan. Sesuai dengan firman Allah Swt:

"Dan hendaklah ada di antara kamu sekelompok orang yang menyeru kepada kebajikan, menyuruh yang ma'ruf, dan mencegah dari yang munkar, mereka itulah orang-orang yang beruntung” (QS. Ali “Imran: 104).

Diantara kehidupan bermasyarakat diperlukan hubungan yang erat. Dengan hubungan yang baik, tiap orang mampu saling menasihati menyeru kepada kebaikan. Sebagai umat muslim, saling mengingatkan adalah sangat dianjurkan, hal ini untuk menjaga Islam agar tetap utuh. Aktifitas yang padat mengakibatkan seseorang tidak memiliki banyak waktu 
untuk mengikuti pengajian atau menghadiri majlis yang diadakan. Ketika seseorang tidak memiliki banyak waktu menghadiri acara keagamaan, perlu orang-orang terdekat untuk saling mengingatkan dan menasihati. Orang yang memiliki waktu untuk menghadiri pengajian, bisa menyampaikan kepada orang lain tentang isi dari yang disampaikan. Cara penyampaian bisa dilakukan dimana saja, selama tempat tersebut memungkinkan. Contoh, kantor, kampus, kantin, kendaraan umum dan tempat yang lain. Adanya orang yang menyampaikan ke orang lain, merupakan bagian dari dakwah untuk menjaga keutuhan agama. Dakwah juga berarti perhatihan kepada orang lain, agar umat muslim selamat secara bersama-sama baik didunia maupun di akhirat. Firman Allah SWT:

"Berikanlah peringatan karena peringatan itu bermanfaat, ia akan mengingatkan orang yang takut (kepada Allah), dan orang yang celaka akan menjauhinya, (yaitu) orang yang akan memasuki api yang besar (neraka)" (QS. Al-A'la: 9-12).

Dakwah yang dilakukan lebih mudah apabila dilakukan dalam sebuah kelompok atau komunitas. Biasanya diantara kelompok atau komunitas sudah terjalin hubungan yang baik, komunikasi juga akan berjalan lebih lancar. Dakwah yang dilakukan dalam sebuah kelompok atau komunitas lebih mudah diterima, masing-masing orang saling mengenal. Ketika seorang berdakwah, akan lebih cepat diterima apabila yang disampaikan bisa menyentuh hati. Suatu kalimat yang mampu menyentuh hati, akan mengubah sikap dan perilaku. Apa yang disampaikan akan selalu tertulis jelas dan diingat.

Pendidikan merupakan sistem dan cara meningkatkan kualitas hidup dalam segala bidang sehingga dalam sepanjang sejarah hidup umat manusia hampir tidak ada yang tidak menggunakan pendidikan sebagai sarana pembudayaan dan peningkatan kualitasnya, meskipun dengan sistem dan metode yang berbeda sesuai dengan taraf hidup dan budaya masyarakat masing-masing. Bahkan pendidikan juga dijadikan sarana penerapan pandangan hidup. ${ }^{1}$ Karena pentingnya berdakwah untuk menegakkan kebenaran maka dakwah melalui pendidikan melalui beberapa bidang yang notabennya sangat dibutuhkan itu dirasa perlu dan baik untuk diterapkan pada masyarakat Indonesia.

\section{PEMBAHASAN}

\section{Pengertian Pendidikan dan Dakwah Islam}

1. Definisi Pendidikan

Pendidikan adalah pembelajaran pengetahuan, keterampilan, dan kebiasaan sekelompok orang yang diturunkan dari satu generasi ke generasi berikutnya melalui pengajaran, pelatihan, atau penelitian. Pendidikan sering terjadi di bawah bimbingan orang lain, tetapi juga memungkinkan secara otodidak. ${ }^{2}$ Kata pendidikan itu sendiri berasal dari bahasa Latin yaitu ducare, berarti "menuntun, mengarahkan, atau memimpin" dan awalan $e$, berarti "keluar". Jadi, pendidikan berarti kegiatan "menuntun ke luar". Setiap pengalaman yang memiliki efek formatif pada cara orang berpikir, merasa, atau tindakan dapat dianggap pendidikan. Pendidikan umumnya dibagi menjadi tahap seperti prasekolah, sekolah dasar, sekolah menengah dan kemudian perguruan tinggi, universitas atau magang. ${ }^{3}$

\footnotetext{
${ }^{1}$ Didin Hafidhuddin, Dakwah Aktual, (Jakarta: Gema Insani Press, 1998), hlm 104.

${ }^{2}$ Jhon Dewey, Democracyand Education. (The Free Press. 1916/1944) hlm. 1-4

${ }^{3}$ https://id.wikipedia.org/wiki/Pendidikan
} 
Dalam pengertian yang lain pendidikan adalah usaha sadar yang dilakukan oleh manusia untuk mengembangkan potensi manusia lain atau memindahkan nilai nilai yang dimilikinya kepada orang lain dalam masyarakat. Dan adapun proses pemindahan nilai nilai itu meliputi berbagai cara, yakni: pertama, melalui pengajaran, yaitu proses pemindahan nilai berupa ilmu pengetahuan dari seorang guru kepada murid atau muridnya dari suatu generasi ke generasi berikutnya. Kedua, melalui pelatihan yang dilaksanakan dengan jalan membiasakan seseorang melakukan pekerjaan tertentu untuk memperoleh ketrampilan mengerjakan pekerjaan tersebut. Dan ketiga melalui indoktrinisasi, yang dilakukan agar orang mengikuti saja apa yang dilakukan atau dikatakan oleh orang lain. ${ }^{4}$

Sedang pendidikan kalau dikaitkan dengan Islam adalah proses pertumbuhan dan perkembangan pendidikan yang diselenggarakan oleh umat Islam sepanjang sejarah kedudukan dan peradaban. Dan pengertian pendidikan agama Islam adalah proses dan upaya pembelajaran ajaran Islam kepada anak atau generasi muda agar mereka dapat memahami dan mengamalkan ajaran-ajaran tersebut. ${ }^{5}$ Ada istilah lain dalam pendidikanyaitu pengajaran yang diartikan sebagai proses penyajian bahan oleh seseorang kepada orang lain dengan tujuan agar orang lain itu menerima. Bahannya berupa sesuatu yang dapat berwujud pengetahuan, kecekatan atau ketrampilan, aktivitas serta hasil-hasil budaya pada umumnya. ${ }^{6}$ 2. Dakwah Islam

Menurut Najamudin, Hamdani Khaerul Fikri dalam tulisannya menyebutkan bahwa dakwah dalam artinya yang elementer adalah menyampaikan pesan- pesan suci dan luhur yang bersumber dari ajaran agama. Dalam kehidupan masyarakat Indonesia dakwah telah menjadi bagian dari gerak hidup dan dinamika di Indonesia. Substansi dakwah yang disampaikan setidaknya mencakup dua hal yaitu ajakan berbuat kebaikan dan mencegah berbuat jahat atau penyimpangan. Secara substansial dakwah merupakan pendidikan masyarakat yang dalam pelaksanaannya tidak jauh berbeda dengan cita-cita pendidikan nasional. ${ }^{7}$ Hal ini dapat dicermati dalam Undang-Undang Sisdiknas Bab II Pasal 3 yaitu:

"Pendidikan nasional berfungsi mengembangkan kemampuan dan membentuk watak serta peradaban bangsa yang bermartabat dalam rangka mencerdaskan kehidupan bangsa, bertujuan untuk berkembangnya potensi peserta didik agar menjadi manusia yang beriman dan bertaqwa kepada Tuhan Yang Maha Esa, berakhlak mulia, sehat, berilmu, cakap, kreatif, mandiri dan menjadi warga negara yang demokratis serta bertanggungjawab".

\section{Unsur-Unsur Pendidikan dalam Dakwah Islam}

Setiap kegiatan yang berkesinambugan dan intensif, selalu memiliki unsur dan beberapa elemen lainnya yang saling mendukung. Seperti aktivitas pendidikan, ada tenaga pengajar, materi yang dipelajari, dan proses kegiatan belajar mengajar. Kegiatan dalam bidang informasi (Media), ada reporter, berkas dan arsip, materi retorika dan sarana

\footnotetext{
${ }^{4}$ Mohammad Daud Ali, Habibah Daud, Lembaga Lembaga Islam Di Indonesia (Jakarta; Raja Grafindo Persada, 1995), hlm 137

${ }^{5}$ http://dokumenqu.blogspot.com/2019/08/pendidikan-dan-dakwah-dalam.html

${ }^{6}$ Ign. S. Ulih Bukit Karo-Karo, et. al., Metodologi Pengajaran, (Salatiga: CV. Saudara, 1981), hlm: 3-4

${ }^{7}$ Najamudin, Hamdani Khaerul Fikri, 2015, "Strategi dan Gerakan Organisasi Dakwah dalam Pengembangan Agama”, Komunike, Volume 7 Nomer 2, Desember 2015, h: 53

${ }^{8}$ Undang-undang Sisdiknas Bab II Pasal 3
} 
informasi. Begitu juga Islam, ada unsur pokoknya, atau yang lebih kita kenal dengan rukun. Begitu juga iman. Dan semuanya ini meiliki peran penting dalam mencapai tujuan. Hal serupa juga ada pada dakwah, yang memiliki unsur pokok atau rukun.

Dakwah dalam Islam tidak terlepas dari tiga pokok: Kegitan dakwah, orang yang berdakwah dan orang yang didakwai,, adapun metode penyampaian dakwah terhadap orang yang akan didakwahi merupan unsur tambahan nomor empat, sedangkan berdakwah dengan gaya tersendiri dan cara tertentu dikategorikan rukun dakwah nomor lima.

Lima rukun dakwah ini disepakati oleh ulama dan dan sudah termasuk di dalam buku dakwah Islam. Namun para ulama berbeda pendapat dalam bidang dakwah ini pada "pengaruh dan target dakwah" Menurut DR.Mushtafa Ibrahim pengaruh dan terget dakwah bukanlah sesuatu yang pokok. Seperti wudhu' dan ruku' dalam sholat. Whudu' adalah syarat dilaksanakan di luar sholat, sedangkan ruku' adalah rukun, dilaksanakan dalam sholat itu sendiri.

Salah satu tiang yang sangat penting dalam penyebaran ajaran Islam adalah pendidikan dan dakwah karena melalui proses pendidikan dan dakwah seluruh nilai, normanorma dan pengetahuan ditransformasikan atau ditransmisikan dari generasi ke generasi berikutnya. Betapa pentingnya pendidikan dan dakwah untuk perkembangan agama Islam. Tidak berlebihan jika agama Islam masuk dalam tipologi agama misionaris, yaitu agama yang dikembangkan melalui dakwah. ${ }^{9}$

\section{Tujuan Pendidikan dan Pendidikan Islam}

Menurut Zainul Ismanto ditinjau dari tujuan operasional dari pendidikan Islam adalah Pertama, Membentuk manusia muslim yang disamping dapat melaksanakan ibadah mahdhah juga dapat melaksanakan ibadah muammalah dalam kedudukannya sebagai orang perorangan atu sebagai anggota masyarakat dalam lingkungan tertentu. Kedua, Membentuk warga negara yang bertanggung jawab kepada masyarakat dan bangsanya dalam rangka bertanggung jawab kepada Allah penciptanya. Ketiga, Mengembangkan tenaga ahli dalam bidang ilmu (agam dan ilmu Islami lainnya).

Pendidikan Islam yang dahulu dilakukan Nabi bertujuan untuk membina pribadi muslim agar menjadi kader yang berjiwa kuat dan dipersiapkan menjadi masyarakat Islam, mubalig, dan pendidik yang baik. Selain itu, pendidikan Islam juga untuk membina aspekaspek kemanusiaan dalam mengelola dan menjaga kesejahteraan alam semesta.

Secara umum, pendidikan Islam memiliki tujuan sebagai berikut:

1. Mewujudkan manusia yang berkepribadian Islam

2. Melatih dan membimbing agar peserta didik menguasai tsaqafah

3. Melatih dan membimbing peserta didik agar dapat menguasai ilmu kehidupan (IPTEK).

4. Melatih dan membimbing peserta didik agar memiliki ketrampilan yang memadai.

Menurut Hasan Langgulung, tujuan-tujuan pendidikan agama harus mampu mengakomodasikan tiga fungsi utama dari agama, yaitu fungsi spiritual yang berkaitan dengan akidah dan iman, fungsi psikologis yang berkaitan dengan tingkah laku individual

\footnotetext{
${ }^{9}$ Muthi'atus Sholihah, Makalah Metode Dakwah Melalui Lembaga Pendidikan (Semarang; UIN Walisongo, 2017)
} 
termasuk nilai-nilai akhlak yang mengangkat derajat manusia ke derajat yang lebih sempurna, dan fungsi sosial yang berkaitan dengan aturan-aturan yang menghubungkan manusia dengan manusia lain atau masyarakat. Hal tersebut menegaskan bahwa tujuan pendidikan Islam berpijak pada nilai-nilai Islam itu sendiri. Sementara itu, Ali Yafie menyebutkan bahwa pendidikan agama Islam mempunyai kontribusi yang penting, karena pendidikan agama Islam dapat meningkatkan wawasan keislaman masyarakat, sehingga dapat memahami dan menghayati ajaran agama yang akan mengantarkan kepada pengamalan yang sempurna.

Al-Abrasyi berpendapat bahwa pembentukan moral yang tinggi adalah tujuan utama dari pendidikan Islam. Pendidikan budi pekerti adalah jiwa dari pendidikan Islam, dan Islam telah menyimpulkan bahwa budi pekerti dan akhlakadalah jiwa pendidikan Islam. Al-Abrasyi menyertai argumennya tentang tujuan pendidikan Islam dengan dalil dari al-Qur'an dan hadits.

\section{Dakwah Islam Melalui Lembaga Pendidikan}

Pendidikan adalah usaha sadar yang dilakukan oleh manusia untuk mengembangkan potensi manusia lain atau memindahkan nilai nilai yang dimilikinya kepada orang lain dalam masyarakat. Dan adapun proses pemindahan nilai nilai itu meliputi berbagai cara, yakni: pertama, melalui pengajaran, yaitu proses pemindahan nilai berupa ilmu pengetahuan dari seorang guru kepada murid atau muridnya dari suatu generasi ke generasi berikutnya. Kedua, melalui pelatihan yang dilaksanakan dengan jalan membiasakan seseorang melakukan pekerjaan tertentu utnuk memperoleh ketrampilan mengerjakan pekerjaan tersebut. Dan ketiga melalui indoktrinisasi,yang dilakukan agar orang mengikuti saja apa yang dilakukan atau dikatakan oleh orang lain.

Menurut UU No. 20 tentang Sistem Pendidikan Nasional, Pendidikan adalah "usaha sadar dan terencana untuk mewujudkan suasana belajar dan proses pembelajaran agar peserta didik secara aktif mengembangkan potensi dirinya untuk memiliki kekuatan spritual keagamaan, pengendalian diri, kepribadian, kecerdasan, akhlak mulia, serta keterampilan diperlukan dirinya, masyarakat, bangsa, dan negara.

Lembaga pendidikan adalah lembaga atau tempat berlangsungnya proses pendidikan atau belajar mengajar yang dilakukan dengan tujuan untuk mengubah tingkah laku individu menuju ke arah yang lebih baik melalui interaksi dengan lingkungan sekitar.

Selain itu, lembaga pendidikan adalah sebuah institusi pendidikan negeri ataupun swasta yang menawarkan pendidikan baik bersifat umum ataupun khusus. Lembaga pendidikan juga merupakan sebuah institusi sosial yang menjadi agen sosialisasi lanjutan setelah lembaga keluarga. Fungsi Pendidikan Menurut David Popenoe adalah sebagai berikut;

1. Transmisi (pemindahan) kebudayaan

2. Memilih dan mengajarkan peranan sosial

3. sekolah mengajarakan corak kepribadian

4. Sumber inovasi sosial

Sedangkan fungsi pendidikan menurut Horton dan Hunt dari segi fungsi manifest pendidikan, yaitu: 
1. Mempersiapkan anggota masyarakat untuk menacari nafkah.

2. Mengembangkan bakat perseorangan demi kepuasan pribadi dan bagi kepentingan masyarakat.

3. Melestarikan kebudayaan.

4. Menanamkan keterampilan yang perlu bagi partisipasi dalam demokrasi.

Dari keterangan di atas dapat diambil tujuan dari diadakannya pendidikan Islam adalah agar dapat menumbuhkan dan mengembangkan dalam diri manusia empat rasa tanggung jawab, yakni;

1. Tanggung jawab kepada Allah,

2. Tanggug jawab kepada hati nuraninya sendiri,

3. Tanggung jawab kepada masyarakat, dan

4. Tanggung jawab dan memelihara semua yang terdapat di langit dan dibumi.

\section{Sasaran Dakwah}

Masyarakat yang menjadi sasaran dakwah, adalah masyarakat yang haus hiburan. Mereka menerima pesan-pesan tersebut selagi tuntunan itu mengandung unsur hiburan. Sehingga dakwah menjadi pesan yang menghibur. Da’ $i$ seakan menjadi pemain panggung, yang harus pandai berimprovisasi, demi kepuasan audiens. Ini hanya salah satu contoh di mana kegiatan dakwah berhadapan dengan komunitas yang beraneka ragam budayanya, hobinya, tingkat pendidikannya, tingkat ekonominya, tetapi dipersatukan oleh persamaan kebutuhan, dan kebutuhan itu dicoba penuhi melalui kegiatan dakwah.

Ajaran Islam yang dibawa Nabi Muhammad SAW sangat luas, mencakup semua bidang kehidupan manusia. Tak hanya soal fikih dan ibadah, namun ajaran Islam juga menyangkut kehidupan sosial masyarakat dalam kehidupan sehari-hari.

Dakwah atau menyuruh kepada yang ma'ruf merupakan salah satu prasyarat dalam membangun khairu ummah (umat pilihan). Pada dasarnya, setiap Muslim dan Muslimah diwajibkan untuk mendakwahkan Islam kepada orang lain, baik Muslim maupun Non Muslim. Hal ini didasarkan pada firman Allah SWT dalam surah an-Nahl ayat 125 Artinya "Serulah (manusia) kepada jalan Tuhanmu dengan hikmah dan pelajaran yang baik dan bantahlah mereka dengan cara yang baik. Sesungguhnya Tuhanmu Dialah yang lebih mengetahui tentang siapa yang tersesat dari jalan-Nya dan Dialah yang lebih mengetahui orang-orang yang mendapat petunjuk"(al-Nahl:125).

Ayat di atas jelas menunjukkan bahwa berdakwah merupakan perintah Allah SWT kepada umatnya, dan perintah Allah SWT itu wajib untuk dikerjakan. Masih banyak firman-firman Allah SWT yang menjelaskan tentang kewajiban berdakwah.Terdapat dalam surat Al-Imran ayat 104 yang artinya "Dan hendaklah ada di antara kamu segolongan umat yang menyeru kepada kebaikan, memerintahkan kepada yang ma'ruf dan mencegah dari yang mungkar." (Q.S. Ali Imran, 3: 104).

Maksud ayat yang diatas yaitu jadilah kamu sekelompok orang dari umat yang melaksanakan kewajiban dakwah. Kewajiban dakwah berlaku bagi setiap muslim, sebagaimana dijelaskan dalam sabda Rasulullah SAW. "Siapa pun yang melihat kemungkaran, maka hendaklah ia mengubah dengan tangannya, kalau tidak mampu, hendaklah mengubah dengan lisannya, kalau tidak mampu hendaklah mengubah dengan hatinya, dan itulah selemah-lemah iman." (HR. Bukhori Muslim). 
Maka dari itu, kita sebagai kaum muslimin harus tahu bahwa dakwah untuk menegakkan ajaran-ajaran Allah SWT merupakan kewajiban yang diperintahkan oleh Allah SWT dan juga menjadi tanggung jawab yang harus dipikul oleh kaum muslimin seluruhnya. Artinya setiap muslim dituntut untuk berdakwah sesuaikemampuannya dan peluang yang dimilikinya. Oleh sebab itu wajiblah bagi kita untuk senantiasa bersemangat dan berpartisipasi dalam berdakwah menyebarkanIslam ke mana pun kita menuju dan di mana saja kita berada.

Berangkat dari penjelasan tersebut bahwa objek dan Sasaran dakwah untuk menyampaikan ajaran Islam pun tak terbatas hanya pada orang-orang yang gemar mendatangi masjid ataupun majelis taklim. Seluruh lapisan masyarakat, termasuk generasi muda yang jarang pergi ke masjid maupun majelis taklim, juga merupakan sasaran dakwah. Mereka membutuhkan pengajaran dan pembinaan yang mampu membimbing langkah maupun pergaulan sehari-hari.

Objek/sasaran dakwah atau disebut dengan Mad'u adalah orang yang menjadi sasaran dakwah, yaitu semua manusia tanpa pandang buluh, sebagaimana firman Allah SWT, Sumber utama yang menjadi dasar bagi sasaran dakwah adalah ayat berikut ini:

"Kamu adalah umat yang terbaik yang dilahirkan untuk manusia, menyuruh kepada yang ma'ruf, dan mencegah dari yang munkar, dan beriman kepada Allah" (QS. Ali Imron: 110).

"Siapakah yang lebih baik perkataannya daripada orang yang menyeru kepada Allah, mengerjakan amal yang saleh, dan berkata: "Sesungguhnya aku termasuk orangorang yang menyerah diri?" (Q. S. Fushshilat: 33)

"Dan suruhlah (manusia) mengerjakan yang baik dan cegahlah (mereka) dari perbuatan yang mungkar dan bersabarlah terhadap apa yang menimpa kamu. Sesungguhnya yang demikian itu termasuk hal-hal yang diwajibkan (oleh Allah)" (QS. Luqman: 17).

Berdasarkan ayat-ayat di atas dapat dipahami bahwa objek dakwah atau sasaran dakwah secara umum adalah seluruh manusia, dan objek dakwah secara khusus dapat ditinjau dari berbagai aspek. Secara khusus sebagai berikut:

1. Aspek usia: anak-anak, remaja dan orang tua

2. Aspek kelamin: Laki-laki dan Perempuan

3. Aspek agama: Islam dan kafir atau non muslim

4. Aspek sosiologis: masyarakat terasing, pedesaan, kota keci dan kota besar, serta masyarakat marjinal dari kota besar

5. Aspek struktur kelembagaan: Priyayi, abangan dan santri

6. Aspek ekonomi: Golongan kaya, menengah,dan miskin

7. Aspek mata pencaharian: Petani,peternak, pedagang,nelayan,pegawai,dll

8. Aspek khusus: Golongan masyarakat tuna susila, tuna netra, tuna rungu, tuna wisma

9. Aspek komunitas masyarakat seniman, baik musik, seni lukis, seni pahat, senitari, dll 


\section{PENUTUP}

Dimasa modern sekarang, banyak berdiri sekolah-sekolah, bahkan tumbuh subur berbagai kampus-kampus baru di daerah. Sekarang sekolah ke-Islaman sudah menjadi trend, banyak orang tua berlomba-lomba memasukan anaknya ke sekolah ke-Islaman.

Semakin banyak sekolah berdiri, menjadi sebuah jalan mempermudah berdakwah. Ilmu yang diberikan memasukan pengetahuan tentang agama. Pemberian pelajaran agama bisa menjadi dasar sebelum ilmu umum diberikan. Agar kelak dengan pengetahuan yang dimiliki bisa untuk kemanfaatan umat manusia, bukan untuk kepentingan materi semata.

Minimnya pengetahuan agama dimasa sekarang, menjadikan generasi muda kurang terkendali. Kegiatan yang dilakukan banyak yang kurang bermanfaat. Beberapa remaja lebih memilih nongkrong di kafe daripada menghadiri masjid. Bahkan bermain game online lebih menyenangkan dibandingkan membaca Al-Quran.

Melalui pendidikan disekolah maupun pendidikan non formal, tiap orang bisa berdakwah sesuai dengan apa yang dipahami. Dimulai dari keluarga, kerabat, tetangga, komunitas sampai di lingkup yang lebih luas. Mengingatkan dan menyampaikan ilmu yang dimiliki adalah sebuah keharusan.

Mengingatkan akan menjaga kelangsungan umat Islam sendiri untuk menghadapi modernisasi. Tidak hanyut dengan berbagai kemajuan yang terjadi. Sedangkan ilmu yang disampaikan akan membuat terus berkembang, menjadi beberapa cabang ilmu dan tentu untuk manfaat yang lebih besar.

Dakwah dan pendidikan yang diberikan berdasar kepada orisinilitas dan kekinian. Orisinilitas berpegang terhadap nilai-nilai Islam dan berdasarkan penemuanpenemuan terbaru dimasa sekarang. Penyesuaian dengan kondisi sekarang sangat penting guna menghadapi segala permasalahan yang nyata.

\section{DAFTAR PUSTAKA}

Abuddin Nata, 1998, Methodologi Studi Islam, Jakarta, PT. Raja Grafindo Persada

Abdul Rahman Shaleh, 2005, Pendidikan Agama dan Pembangunan Untuk Bangsa, Jakarta: PT. Raja Grafindo Persada.

Burhanuddin Wahid, Konsepsi Pemberdayaan Manusia dalam Islam, Semrang: CV. Gha Lilia Indonesia.

Departemen Agama RI, 1998, Al Qur'an dan Tarjamahnya, Jakarta.

Didin Hafidhuddin, Dakwah Aktual, (Jakarta: Gema Insani Press, 1998)

Jhon Dewey, Democracy and Education. (The Free Press. 1916/1944)

Mohammad Daud Ali, Habibah Daud, Lembaga Lembaga Islam di Indonesia (Jakarta; Raja Grafindo Persada, 1995)

Muthi'atus Sholihah, Makalah Metode Dakwah Melalui Lembaga Pendidikan (Semarang; UIN Walisongo, 2017)

Najamudin, Hamdani Khaerul Fikri, 2015, "Strategi dan Gerakan Organisasi Dakwah dalam Pengembangan Agama", Komunike, Volume 7 Nomer 2, Desember 2015

Undang-Undang Sisdiknas Bab II Pasal 3

http://yvansmorphosa.blogspot.com/2014/12/dakwah-dan-pendidikan.html 